\section{Ethno-ecological Observation of Magar of Bukini, Baglung, Western, Nepal}

\section{Prakash Prasad Sapkota ${ }^{1}$}

\begin{abstract}
This study is carried out to explore the socio-cultural condition, knowledge and changing pattern for their environmental adaptation of Magar inhabitant at Bukini Tityang V.D.C. of western Nepal. There are 73 households of 450 population. The major subsistence activity of the local people is agriculture and animal husbandry. The economic condition of the majority of families is medium. Expenditure of the families has been increasing in high rate which raised question about cohesive bond of social structure. Out of total population, $76.67 \%$ are literate that is greater than national level. Young literate people do not have their applied knowledge in agricultural production and are also not attracted as well as interested about it. Most of the people are aware of the health and sanitation. Due to migration from different places co-dominance has occurred between different clans. This phenomenon is not only in cultural activity but also in physical structure of the children. There are 86 plant species used to heal the human and domestic animal diseases, 17 species for fodder, 14 species for making
\end{abstract}

1 Mr. Prakash Prasad Sapkota is an Assistant Lecturer at the Department of Sociology/Anthropology, Mahendra Multiple Campus, Baglung. agricultural equipment, 25 species as wild fruits and 23 species for different rituals and ceremonies. The elder Magars are rich in indigenous knowledge while the younger are not. If older generation dies their knowledge will be vanished. The effect of modernization and acculturation leads towards the increasing rate of dependency about fooding, clothing and recreation activity which directly change the behavior of the local people.

Key Words: Ethnic group, Indigenous knowledge, ethnoecology; Magar, Baglung, Nepal.

\section{Introduction}

This research paper is divided into three sections; i) present socio-cultural condition, ii) ethnic knowledge about the medicinal plants and iii) changing situation for the adaptation with their environment of Magar inhabitant at Bukini Tityang, western Nepal. The results are based on the primary data collected from the field.

\section{Theoretical Perspective: A Brief Sketch}

The socio-cultural study of ethnic groups is not new in Nepal. But different ethnic groups have different socio-cultural traits. In case of some groups, it varies according to geographical to social access. So finding of one study can deviate from one ethnic group to another and within ethnic group also as they adopt in different was in the environment. The ethnic study in the country has been accelerating due to its importance in policy making. The powerful force of modernization, westernization, globalization and dependency has threatened social structure and all cultures and cultural values of indigenous people. 


\section{Dhaulagiri Journal of Sociology and Anthropology Vol.2 | 229}

Anthropology as a holistic discipline covers most of the aspects of human beings and their socio-cultural behaviour. Each and every society develops its culture for better adaptation. The changing pattern of ecology, social structure and cultural modification occur for readjustment. The natural interest and methods of anthropology are quite consistent with work that has defined a number of important social and cultural variables that have had considerable impact in any field related with society and their culture (True, 1990). The anthropological investigation analyses any social problem from inside and through local eyes, language, culture and values.

Indigenous knowledge is defined as the accumulated knowledge, skills and technology of people, derived from the direct interaction of human beings and their environment. It is the sum of experiences and knowledge of a given group that forms the basis for decision making in the face of familiar and unfamiliar problems and challenges. Indigenous knowledge is initiated, derived and evolved by the local people themselves (Tamang \& Gill, 1993, Rohana and Gunning, 1994). Native people have a stock of indigenous knowledge and experience, traditional technology, skill and innovation which is helping them to survive in the holistic environment. As indigenous people are observed into the mainstream societies, there would be loss of undocumented indigenous knowledge which would be to scientists trying to learn the sustainable way of existence with the nature (Gurung, 1994). Anthropologist has made substantial contributions towards a better understanding of traditional and indigenous resource management practice in Nepal.

Ethno-botany was first coined by American Botanist John W.

\section{$230 \mid$ Prakash Prasad Sapkota}

Harshberger in 1895, as the study of plants used by native community. It is a multidisciplinary approach blending the method and information from both anthropology and botany. To study the people in depth of any community, human ecological approach, environmental possibilism approach, ethno-ecological approach, ethno-botanical approach etc. are developed. These are the fields of cognitive anthropology which emphasize the perceptual environment of a particular culture. Ethno-botany emphasizes the people plant relation, their native knowledge to adopt their environment. It emphasizes the "people way of life, culture and plant resources" and its method includes the intimate participation in a community and the organization of social life (Keesing, 1998). Medicinal plant is one of the most important parts of ethno-botany which concerns about the health cure of man and his domestic cattle in certain environment for easy adaptation.

A major section of population in Nepal is composed of many ethnic groups. There are several aspects which illustrate the significance of ethnic groups. But we have failed to through ample of light on their cultural, social and indigenous knowledge till now. Traditions, beliefs, morals, customs, religion, economic condition, education and indigenous knowledge of plants have significant role in the national culture and national building activities.

In concern to socio-cultural changes, various theories were postulated on development, like modernization theory, dependency, world system and people centered theories, to understand the problem of people and to solve it. But without finding the primary problem theories are directly imposed in our society and culture. The native people are not ready to 
rely on these accepted theories which destroy the ethnic knowledge continuously for the adaptation to their environment and increase dependency in high rate. Due to increase in the selfish motive, attitude and psychology unhealthy competition is increasing conflict day by day, which lead the negative sign in the development of social and cultural activities.

\section{Study Area}

The study area, Tityang VDC, ward no. 8, Bukini village, is located in Southern part of Baglung Municipality of Baglung district, Nepal. The area is north flank of Bhakunde hill and is about one hour walk from the head quarter of Baglung. The Bukini village lies in $1100 \mathrm{~m}$. height from the sea level. The terraced land is slopped with sub-temperate climate.

The study area is an agrarian society with homogenous ethnic composition with heterogeneous socio-economic strata. The study area consists of Chiple Magar, Singali Magar, Bagale Magar, Bhujel, Dhemal, Pedalne and Chalise Magar. This study was focused on Magar with homogeneous composition. There are 73 households with population of 450 Magars.

\section{The People}

The Chiple, Singali, Bagale, Bhugal, Dhemal, Pedalne and Chalise Magar are the Magar sub clans settled in Bukini village. They have similar feature with other Magar clans. They are simple having co-operative nature. The people having normal height, Mangolian face with wheat-white in color. The purity of Mongolian face is seen clearly in chiple Magar but other have in between Mongolian and Arayan when noticed on nasal and check bone of the face as well as color. They are facing serious crisis in their socio-cultural activities, which have not been studied from anthropological perspective till now. There was not any authentic written documents about the origin of the Chiple, Singali, Bagale, Bhugal, Dhemal and Pedalne, Chalise, Magar though questioned with some elders, their ancestors were migrated from different parts of Nepal and live in this area. The channel of clan and migration is-

Pala(dhemal)

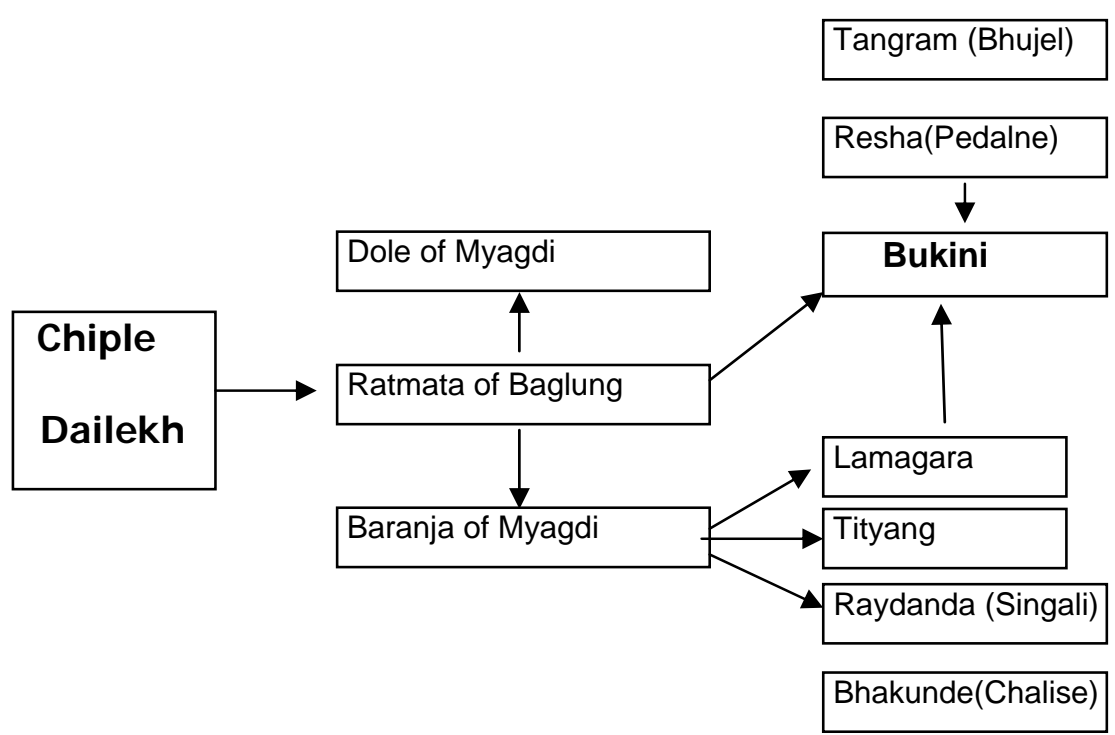

It shows the migration channel.

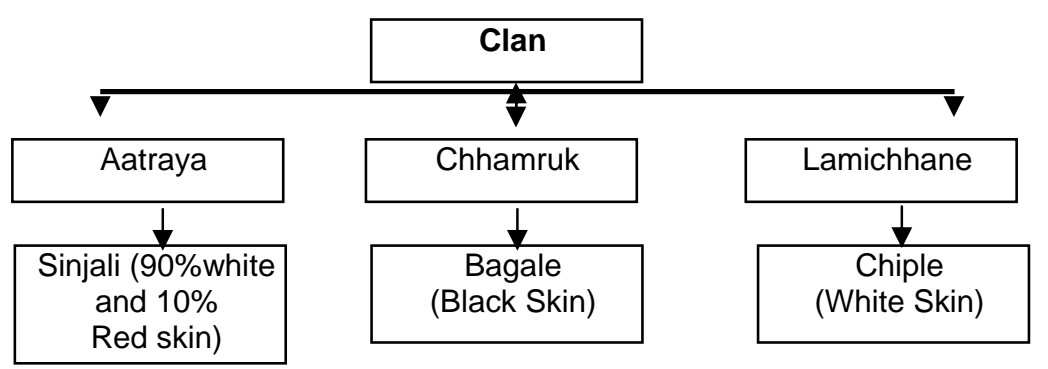

It shows the clan channel according to respondent. 
In "Nepalka Janajatiharu" (Pandey, 2005), among Chiple, Bagale, Bhujel, Pedalne, Chalise, only Singali Thapa Magar is included in the Magar clan.

The elder group has a stock of indigenous knowledge, traditional system of organization and customary concerning the use and the management of plant resource, which could be valuable information about the using pattern, conservation and management before it is lost. Their knowledge is most important for socio-cultural identity, sustainable local level development as well as preservation of their culture and knowledge about people-plant relationship. The distinct generation gap is seen within elder and younger. The younger groups are mostly diffused with other culture. The effect of modernization and westernization is flourishing in younger one which brings the situation of extinction of their cultural identity.

\section{Material and Method}

Indigenous knowledge, we see today are the outcome of accumulated experiences with plant-people relationship to maintain their socio-cultural identity. These were carried over generation without any written documents. This paper focus on the present socio-cultural condition, indigenous knowledge and their relation with plants.

The data are based on the field studies applying observation, interview, participation and household survey. The field study was carried out in March 2008, with a focus of a wide range of socio-cultural and ethno-botanical aspect at Bukini village having 73 households. The methods were applied to collect the data on ethno-history, legends, rituals, ceremonies and their genealogical history. For the ethno-botanical data collection artifact interview was taken. Secondary data were collected from GOs, school, health centre, political leaders, social workers, relevant document, literature and publication to the related topics and were analysed descriptively.

\section{Economy}

The major subsistence activity of the local people is agriculture and animal husbandry. The productivity of the land is good near the stream-side due to irrigation facility and fertility of soil, but such type of land is less. Low productive land is called Bari where maize (Zea mays), millet (Eleusine coracana L), Potatoes (Solanum tuberosum) etc, are grown. They are economically and ecologically important product of this region. The irrigated low land is called Khet on which rice is grown is not sufficient with them and two family do not own any kind of land. Agricultural works are carried out almost around the year, maize, millet, wheat, rice are the main crops of this area. Beside the agricultural work some of the men do serve in army and only a few of them engage in other government services. In spite of the agricultural work, women are engaged in preparing local wine. For the first time, her husband gives some money called 'doko halne', then she should collect money for her personal expenditure by preparing and selling of wine. Animal husbandry is another important subsistence strategy adopted by local people which is closely related with agricultural production system. Buffalo, pig, cow, goats and fowls (chickens) are the main leivestock of Bukini village. Dudhilo (Ficus nerifolia), Khanyo (Ficus semicordata), Kutimro (Litsea monopetala), Badahar (Ficus Sp.) Baans (Dendrocalus Strictus), Kapro (Ficus Lacor) and Phadelo are main fodder plants. Other fodder plants are used as according to the no. of cattle and their necessity.

\section{Education/Health}

Most of the people of Bukini are aware about the education and sanitation. A male has passed M.A., one man and a woman have passed B.A, five boys and three girls have 
passed I.A., 20 people have passed SLC. Elder 75 women and 30 men are illiterate, which cover $23.33 \%$ of their population. Children above five years are going to school. So the average literacy rate is $76.67 \%$ which is greater than national literacy rate.

Most of the people are aware of the health and sanitation. They have been using tap water. Most of the houses have toilet and people use it. In front of Chiple's house, has pig khor and optional for other which increase the pollution of the house's environment but they adopt on it. Man and woman do share work and both are equally participating for the decision making activity. Though few members of women are participating in social work but they have not known about there right all. Family members of a house take part in discussion before deciding every major works, most of the decisions are made by elder male. Polygamy marriage system has started to change into monogamy. Love and capture marriage is frequent but arranged marriage is less in number because in arranged marriage rupees (5000 to 18000) five thousands to eighteen thousands cash, gold, clothes, wine, chicken and pig should be given as gift for bridegroom in different sub clans of Magars. By the expression in Mela and individual contact boy and girl express their love to each other. If both were agreed there are no objections from their parents.

\section{House}

The Magars of Bukini are skill-full to build houses, cutting stones and fishing. Their houses are made up of stone and mud wall with stone roofing mostly. Some of the houses are tin as well as nine houses are thatch roofing. At the time of building house, each house contributes two to four days help voluntarily to complete. It is an important symbol of cooperation among them.

\section{Language}

Magars speak Nepali language though their ancestors have their own Kham language. When they migrated from different places, they slightly left their own language to speak and were familiar with local Nepali language. There is no one to speak their own language. They totally adopted Nepali language in this environment.

\section{Fooding and Clothing}

Most of the Magars take meat. They use domestic animals like goats, sheep, fowls, buffalos, pig and fish as well for meat and milk. Culturally Chiple use pig meat in special occasion of feast and festivals and other use fowls \& fish. Their staple food grains are maize, millet, wheat and rice. Most of the cultural activities need liquor. So, young to adult person including women also take liquor. Like the habitation of sub-tropical climate, northern flank of hill, older men wear shirt, half-shirt, Jange(half-pant), kachad(white simple towel), cap and east-coat but younger have shirt and pant mainly. In cold season they wear woolen clothes. Women wear phuli, bulaki, shellac, rings on fingers and necklace of colored glass bead. The young women wear tuki, rings on finger, shellac, necklace. Elder men wear khadi and women use burko in special occasion. cholo, patuko, T-shirt, gaaun and lungi are the popular clothes of young women.

\section{Feast and Festivals}

The Magars of Bukini believe that god created human beings seen in their legends. Their behavior is guided by their religious norms and values which make them more cohesive group. They were entertained with many festivals which are major aspect of people's life. Religion, ethnic festivals and rituals help reinforce and increase group participation which led towards we feeling. They celebrate Baishaki Purni and 
pray Baraha god by using pig sacrificed and offered to deity, wine, jand, flower, aaccheta and paati alternately in a year for saving member of the family, good agricultural production and animal husbandry. Dhule is also called Petri karya. It is carried out in Jestha's any Monday with fish sacrificed and in shrawan with pig's sacrificed took entertained called Harelo. It is most important ritual for them. All the members of Magars gather and pray their ancestors for all aspects wellness of the family. Each house at least one black pig should be raised to sacrificed in Petri karya. In front of a house a cage of pig having at least one black pig is a symbol of chiple and sacrificed chicken in haralo. They celebrate Sawane Sakranti. They use many medicinal herbs at that time, they throw, (fling) the burning wood pieces one by one in all direction by saying the following words.

Luto laiza pilo laiza dhairinge gada, Pangali pada ho .........(east)

Luto laiza pilo laiza Sigane gada Pangali pada ho.........(south)

Luto laiza pilo laiza pulami gada Baglunge pada ho ...(north)

Remembering their god and they cross their houses by the burning wood. They celebrate Teej, Dashain, Diwali panchami, Chaitra Dashain, Mai pujne and Tihar. In Tihar, married sister brings selroti (saliny vermicelli fried from the meal of rice in ghee), chicken, wine and a pig as a present for their brothers is called Tihar khoune. Brothers give money and putting tika and mala for their sisters.

\section{Song and Dance}

Kirtan \& ratauli are the song and dance which are used in different ceremony of Bukini, Magar Sorathi purbura and Jhamre are nearly extinct. Most of the younger start to practice the modern song and dance. Due to migration from different places their song, dance as well as cultural activities are fused and no new one is developed till now. It leads towards their previous cultural identity.

\section{Life Cycle Rituals}

Married pregnant woman is not allowed to keep jal(pure water) for their gods and goddesses. Her husband should not touch the dead body but can participate a mourner at a funeral. He is forbidden to cut animals. At the birth time an experienced old women care the child. The placenta is buried in secrete place with leaf plate. On $9^{\text {th }}$ day Magar's Brahmins "Bhanja" gives name the newly born child. Nawaran takes place on $9^{\text {th }}$ day for both son and daughter. The delivery pollution is completed after the bathing of mother and spread the urine of cow for purity to their houses. The economically strong family gives money with tika for Kanya. Relatives give aasis (blessing) with putting tika for new child saying "Pray with god for long life, would be join in Army with high rank like jamdar, were sindur of king but aasis is changed into for greater education, spread like as $d u b o$, unshaken like as Dhaulagiri Himal and for long life. Bratabanda [Chhewar] is carried out in odd year of boy. In Bratabanda, they prepare the four sided square [Chauko] having five paiyun (Prunes coracoid's D. Don) and leaf of banana (Muse paradisiacal) around it. By searching auspicious situation, direction, time and people throw the head hair of boy. The boy wears the ring of wheat powder on ear and small gold on tuft of hair [tupi]. The boy prays for god and goddesses. They arrange party if the economic condition is good with pig and fowl meat. Arranged, Vagaune, and love marriage system are popular. When boy and girl want each other, they spent some days in different place and return in boy's house. Girl enters with burning lamp and putting tika by her boy's mother and father called "Vitraune". In previous time they do not use sindur which is in practice now. The boy puts sindur on her head. Tulsi pani, kapur \& ghee are kept on mouth of dead body. The dead body is kept on the ladder prepared by 
bamboo and covered by kora and yellow-red pat. They think pat is a special and pure cloth use to remove polluted situation. Interested food, wine, kapur, shrikhanda, rice, flower etc. are put on dead body and brings at Kali Gandaki with spreading [the mixture of fried rice, aabir, coin \& flower] la on crossing of the road as well as they use to bang a conch now. The entire mourner provides jal [river water] in the mouth of the dead body and finally gives dagbatti by elder son and burry into the bank of the river. The death pollution is completed in eleven days. In eleventh day, at three AM son bath and prepares 22 pindas (rounded structure of rice \& ghee) and kept on the small branches of Jhakro, symbol of soul. Then after bathing and putting tika they arrange party. All the polluted materials are burried by bhanja and spread mixture of cow urine, ghee, cow milk with dubo for purity of the house. The life cycle rites have slight different between the different varieties of the Magars of this area.

\section{Ethno-botany}

Ethno-botany is the science which studies the use, beliefs and perceptions of plant resources by particular society contributed scientifically in the development of human civilization. Ethno-botany can effectively assist conservation in Nepal because traditional societies have a vast knowledge of the plants as compared to so-called advanced societies. Cultivating the latest knowledge of traditional plant users can help not only in sustainable use of resources but also in conservation and community development.

Ethno-botany \& ethno-zoology provide ample possibilities for demonstrating the principle of taxonomy in native terminological system (Conklin, 1972). Ethno-botany helps us to understand the use and classification of natural resources across the entire set of specimen collected or categories elicited (Martin, 1995). Ethno botanist collects details information from local level to understand the situation, cultural aspects of the development and conservation. Magars of Bukini, have knowledge and the way of traditional healing practice. They settle near the district headquarter and influenced by modernization and in present situation the older generation have knowledge about the medicinal plants and left to do the practice. This knowledge will be vanished in near future.

There are 86 plant species used to heal the human and domestic animal diseases. Those consists herbs, shrubs, climber and trees. Mostly they use root and rhizome, leaf, bark, flower, fruit, seed and the whole plant according to the nature of diseases and the properties of the plant parts. Some of them are given in the table 1 .

Table 1 : Major medicinal plants used in practice

\begin{tabular}{|c|c|c|c|c|c|}
\hline $\begin{array}{l}\text { S. } \\
\text { N. }\end{array}$ & $\begin{array}{l}\text { Nepali/ } \\
\text { Local } \\
\text { name }\end{array}$ & $\begin{array}{c}\text { English } \\
\text { name }\end{array}$ & $\begin{array}{c}\text { Scientific } \\
\text { name }\end{array}$ & $\begin{array}{l}\text { Parts } \\
\text { used }\end{array}$ & Uses \\
\hline 1 & Aank & $\begin{array}{l}\text { Giant } \\
\text { milk }\end{array}$ & $\begin{array}{l}\text { Calotrops } \\
\text { gigantea L. }\end{array}$ & $\begin{array}{l}\text { Latex, } \\
\text { Root }\end{array}$ & $\begin{array}{l}\text { 1-2 drops of latex with a } \\
\text { glass of water is applied to } \\
\text { control dysentery and } \\
\text { expectorant. Plants used in } \\
\text { white leprosy and skin } \\
\text { disease. }\end{array}$ \\
\hline 2 & Aaru & Peach & $\begin{array}{l}\mathrm{Pr} \\
\mathrm{pe}\end{array}$ & $\begin{array}{l}\text { Bark and } \\
\text { shoot, }\end{array}$ & $\begin{array}{l}\text { Bark and shoot paste is } \\
\text { used in infected wound for } \\
\text { some days. }\end{array}$ \\
\hline 3 & Abijalo & $\begin{array}{l}\text { Lightning } \\
\text { weed }\end{array}$ & $\begin{array}{l}\text { Dymaria } \\
\text { diandra } \\
\text { Bblume L. }\end{array}$ & $\begin{array}{l}\text { Whole } \\
\text { plants }\end{array}$ & $\begin{array}{l}\text { Juice of plants is used to } \\
\text { cure for stomachic disorder } \\
\text { and sinuses. }\end{array}$ \\
\hline 4 & $\begin{array}{l}\text { Aijeru, } \\
\text { Liso }\end{array}$ & $\begin{array}{l}\text { Strap } \\
\text { flower }\end{array}$ & $\begin{array}{l}\text { Loranthus } \\
\text { falcatus L. } \\
\text { f. }\end{array}$ & $\begin{array}{l}\text { Bark, } \\
\text { fruits }\end{array}$ & $\begin{array}{l}\text { Juice of bark is used in } \\
\text { wounds, } \\
\text { troubles, asthma anstrual } \\
\text { paralysis. }\end{array}$ \\
\hline 5 & Ainselu & \begin{tabular}{|l|} 
Golden \\
evergreen \\
raspberry
\end{tabular} & $\begin{array}{l}\text { Rubus } \\
\text { ellipticus L }\end{array}$ & $\begin{array}{l}\text { Fruits, } \\
\text { roots, } \\
\text { shoot. }\end{array}$ & $\begin{array}{l}\text { Shoot paste is used in } \\
\text { snake's bites. Root juice for } \\
\text { fever \& fruit for appetite. }\end{array}$ \\
\hline 6 & $\begin{array}{l}\text { Akashbeli } \\
\text { jeli }\end{array}$ & Dodder & $\begin{array}{l}\text { Cucuta } \\
\text { reflexa } \\
\text { Roxb. }\end{array}$ & $\begin{array}{l}\text { Whole } \\
\text { plants }\end{array}$ & $\begin{array}{l}\text { Juice of fresh plant or the } \\
\text { decoction is mixed with } \\
\text { Ghodtapre and kurkure that } \\
\text { given to the patients of } \\
\text { jaundice and fever. }\end{array}$ \\
\hline 7 & Amala & Indian & $\begin{array}{l}\text { Phyllanthus } \\
\end{array}$ & Fruits & Mixed with harro it is used \\
\hline
\end{tabular}


Dhaulagiri Journal of Sociology and Anthropology Vol.2 | 241

\begin{tabular}{|c|c|c|c|c|c|}
\hline & & \begin{tabular}{|l|} 
goose \\
berry
\end{tabular} & cmblica L & & $\begin{array}{l}\text { to cure for gastritis, cough } \\
\text { and appetizer. }\end{array}$ \\
\hline 8 & Amaro & $\begin{array}{l}\text { Golden } \\
\text { apple }\end{array}$ & $\begin{array}{l}\text { Spondias } \\
\text { pinnata L. }\end{array}$ & $\begin{array}{l}\text { Bark, } \\
\text { fruit }\end{array}$ & $\begin{array}{l}\text { Bark juice is used for joint } \\
\text { pain and fruit in cough, } \\
\text { rheumatism } \\
\text { insecticidal. }\end{array}$ \\
\hline 9 & Amriso & $\begin{array}{l}\text { Broom } \\
\text { grass }\end{array}$ & $\begin{array}{l}\text { Thysanolae } \\
\text { na maxima } \\
\text { L. }\end{array}$ & Root & $\begin{array}{l}\text { Roots juice is applied in } \\
\text { fever and wounds. }\end{array}$ \\
\hline 10 & $\begin{array}{l}\text { Anar, } \\
\text { Darim }\end{array}$ & $\begin{array}{l}\text { Apple } \\
\text { grante }\end{array}$ & \begin{tabular}{|l|} 
Punica \\
granatum \\
L. \\
\end{tabular} & Bark & $\begin{array}{l}\text { Juice of Bark is used for } \\
\text { intestinal disorder and to } \\
\text { kill the worms. }\end{array}$ \\
\hline 11 & Anp & Mango & $\begin{array}{l}\text { Mangifera } \\
\text { indica L. }\end{array}$ & $\begin{array}{l}\text { Bark, } \\
\text { seed. }\end{array}$ & $\begin{array}{l}\text { Bark and seed decoction is } \\
\text { used to cure for gastric in } \\
\text { some days. }\end{array}$ \\
\hline 12 & $\begin{array}{l}\text { Asuro, } \\
\text { Bhasak }\end{array}$ & $\begin{array}{l}\text { Malabar } \\
\text { nut }\end{array}$ & $\begin{array}{l}\text { Adhatoda } \\
\text { vasica L }\end{array}$ & $\begin{array}{l}\text { leaves, } \\
\text { flower, } \\
\text { roots } \\
\end{array}$ & $\begin{array}{l}\text { Decoction of plant is used } \\
\text { for cough, chromic } \\
\text { bronchitis. }\end{array}$ \\
\hline 13 & Bakaino & $\begin{array}{l}\text { China } \\
\text { berry }\end{array}$ & \begin{tabular}{|l} 
Melia \\
aredarach L
\end{tabular} & $\begin{array}{l}\text { Leaf and } \\
\text { bark }\end{array}$ & $\begin{array}{l}\text { Juice of leaf or bark is used } \\
\text { in fever, stomachic worms } \\
\text { and skin diseases. }\end{array}$ \\
\hline 14 & $\begin{array}{l}\text { Ban } \\
\text { Marati }\end{array}$ & - & \begin{tabular}{|l|} 
Spilanthath \\
us \\
ascemella \\
(Linn.) \\
Murr. \\
\end{tabular} & Flower & $\begin{array}{l}\text { Decoction of flowers is } \\
\text { used in cough, cold, tongue } \\
\text { paralysis, toothache and } \\
\text { headache. }\end{array}$ \\
\hline 15 & Bans & $\begin{array}{l}\text { Solid } \\
\text { Bamboo }\end{array}$ & $\begin{array}{l}\text { Dendrocalu } \\
\text { s strictus L. }\end{array}$ & $\begin{array}{l}\text { Plants' } \\
\text { sap }\end{array}$ & $\begin{array}{l}\text { Sap is used to control the } \\
\text { urinary problem of } \\
\text { children. }\end{array}$ \\
\hline 16 & Bar & $\begin{array}{l}\text { Banyan } \\
\text { tree }\end{array}$ & $\begin{array}{l}\text { Ficus beng } \\
\text { halensis L. }\end{array}$ & $\begin{array}{l}\text { Latex, } \\
\text { stilt root }\end{array}$ & $\begin{array}{l}\text { Latex used in abscess, stilt } \\
\text { root is used to woman to be } \\
\text { pregnant. }\end{array}$ \\
\hline 17 & $\begin{array}{l}\text { Batul } \\
\text { pate }\end{array}$ & - & \begin{tabular}{|l|} 
Stephania \\
glandulifer \\
a Miers. \\
\end{tabular} & $\begin{array}{l}\text { Leaves, } \\
\text { bulb }\end{array}$ & $\begin{array}{l}\text { Leaves \& bulb juice are } \\
\text { used in gastric. }\end{array}$ \\
\hline 18 & Bel patra & $\begin{array}{l}\text { Wood } \\
\text { apple }\end{array}$ & $\begin{array}{l}\text { Aegle } \\
\text { marmelos L }\end{array}$ & $\begin{array}{l}\text { Fruit, } \\
\text { root }\end{array}$ & $\begin{array}{l}\text { Fruit juice is used to } \\
\text { control diarrhea, dysentery } \\
\text { and the root juice is used in } \\
\text { fever and vomiting. }\end{array}$ \\
\hline 19 & Belauti & Guava & \begin{tabular}{|l} 
Psidum \\
guajava L.
\end{tabular} & Bark & $\begin{array}{l}\text { Bark juice is used to cure } \\
\text { in diarrhea. }\end{array}$ \\
\hline 20 & Bet lauri & - & \begin{tabular}{|l} 
Costus \\
speciosus \\
(Koening.) \\
Sm. \\
\end{tabular} & $\begin{array}{l}\text { Root } \\
\text { stock }\end{array}$ & $\begin{array}{l}\text { Juice used to cure of fever, } \\
\text { cough, and pain and as } \\
\text { tonic. }\end{array}$ \\
\hline 21 & Bethe & $\begin{array}{l}\text { Lamb's } \\
\text { quarter }\end{array}$ & \begin{tabular}{|l} 
Chenopocli \\
um album \\
$\mathrm{L}$
\end{tabular} & \begin{tabular}{|l|} 
Root, \\
shoot and \\
leaves \\
\end{tabular} & $\begin{array}{l}\text { It is used to cure of } \\
\text { children pneumonia. (Bal } \\
\text { roga). }\end{array}$ \\
\hline 22 & Bhede & Purple & Barleria & Leaf & Leaf paste is used in \\
\hline
\end{tabular}

242 | Prakash Prasad Sapkota

\begin{tabular}{|c|c|c|c|c|c|}
\hline & kuru & hair dye & $\begin{array}{l}\text { crislata } \\
\text { Linn. }\end{array}$ & & aches and skin diseases. \\
\hline 23 & Bhorla & $\begin{array}{l}\text { Camel's } \\
\text { foot } \\
\text { climber }\end{array}$ & \begin{tabular}{l|} 
Bauhinia \\
vahlii \\
Wight. \& \\
Arn.
\end{tabular} & Seeds & $\begin{array}{l}\text { Seeds are used in } \\
\text { stomachic disorders and for } \\
\text { tonic. }\end{array}$ \\
\hline 24 & Bhringraj & $\begin{array}{l}\text { khaki } \\
\text { weed }\end{array}$ & $\begin{array}{|lr|}\text { Alternanthe } \\
\text { ra } & \text { Sessilis } \\
\mathrm{L} & \\
\end{array}$ & $\begin{array}{l}\text { Whole } \\
\text { plant }\end{array}$ & $\begin{array}{l}\text { Paste of this plant is used } \\
\text { to cure of wounds and } \\
\text { sores. }\end{array}$ \\
\hline 25 & $\begin{array}{l}\text { Bhui } \\
\text { kaphal, } \\
\text { Sarpa } \\
\text { kaphal }\end{array}$ & $\begin{array}{l}\text { Strawberr } \\
\mathrm{y}\end{array}$ & $\begin{array}{l}\text { Fragaria } \\
\text { nubicola } \\
\text { lindl. Ex. } \\
\text { Lacaita. }\end{array}$ & $\begin{array}{l}\text { Leaves, } \\
\text { Flower, } \\
\text { Fruit }\end{array}$ & $\begin{array}{l}\text { Juice is used to control } \\
\text { excessive bleeding during } \\
\text { menstruation, cough and } \\
\text { cold. It is also used in } \\
\text { nerve and to remove fluid } \\
\text { from the lungs. }\end{array}$ \\
\hline 26 & $\begin{array}{l}\text { Bhui } \\
\text { katahar }\end{array}$ & $\begin{array}{l}\text { pine } \\
\text { apple }\end{array}$ & $\begin{array}{l}\text { Ananus } \\
\text { comosus L }\end{array}$ & Fruit & $\begin{array}{l}\text { Fruit is eaten for the cure } \\
\text { of urinary complaints and } \\
\text { internal inflammation of } \\
\text { the body. }\end{array}$ \\
\hline 27 & $\begin{array}{l}\text { Bhyakur, } \\
\text { Kukur } \\
\text { Tarul }\end{array}$ & $\begin{array}{l}\text { Deltiod } \\
\text { yam }\end{array}$ & \begin{tabular}{|lr|}
\multicolumn{2}{|l|}{ Dioscorea } \\
praeri & Prai \\
$\mathrm{n}$ & $\&$ \\
Burkill. & \\
\end{tabular} & $\begin{array}{l}\text { Tuberous } \\
\text { rootstock }\end{array}$ & $\begin{array}{l}\text { Juice is used to control } \\
\text { pregnant. }\end{array}$ \\
\hline 28 & Bojho & $\begin{array}{l}\text { Sweet } \\
\text { flag. }\end{array}$ & $\begin{array}{l}\text { Acorus } \\
\text { calamns L }\end{array}$ & Rhizome & $\begin{array}{l}\text { Juice is used for stomachic } \\
\text { disorders, bronchitis, fever } \\
\text { and it is chewed to clear } \\
\text { the throat and open the } \\
\text { voice. }\end{array}$ \\
\hline 29 & $\begin{array}{l}\text { Chari } \\
\text { Amilo }\end{array}$ & $\begin{array}{l}\text { Pink } \\
\text { wood } \\
\text { sorrel }\end{array}$ & $\begin{array}{l}\text { Oxalis } \\
\text { corymbosa } \\
\text { L. }\end{array}$ & $\begin{array}{l}\text { Leaf and } \\
\text { whole } \\
\text { plant }\end{array}$ & $\begin{array}{l}\text { Juice of leaf is used to } \\
\text { remove the eye dirt, to } \\
\text { control vomiting and } \\
\text { children diarrhea. } \\
\end{array}$ \\
\hline 30 & $\begin{array}{l}\text { Chiraito, } \\
\text { Lektite }\end{array}$ & Chiretta & $\begin{array}{l}\text { Swertia } \\
\text { chirayita L }\end{array}$ & $\begin{array}{l}\text { Whole } \\
\text { plants }\end{array}$ & $\begin{array}{l}\text { Decoction of plants is used } \\
\text { to cure of fever, typhoid, } \\
\text { wounds, cuts, diabetes. }\end{array}$ \\
\hline 31 & Chitu & $\begin{array}{l}\text { White } \\
\text { flower } \\
\text { leadwort }\end{array}$ & $\begin{array}{l}\text { Plumbago } \\
\text { zeylanica } \\
\text { Linn. }\end{array}$ & Roots & $\begin{array}{l}\text { Root paste is applied to } \\
\text { cure of abscess, increase } \\
\text { appetite, and improve } \\
\text { digestion. It is also used to } \\
\text { treat of teeth ache, piles } \\
\text { and diarrhea. }\end{array}$ \\
\hline 32 & Chuttro & Barberry & $\begin{array}{l}\text { Berberis } \\
\text { aristata Dc. }\end{array}$ & Root bark & $\begin{array}{l}\text { Juice or decoction is used } \\
\text { for jaundice, diarrhea, and } \\
\text { fever and eye infection. }\end{array}$ \\
\hline 33 & $\begin{array}{l}\text { Gandhe } \\
\text { jhar }\end{array}$ & $\begin{array}{l}\text { goat } \\
\text { weed }\end{array}$ & $\begin{array}{l}\text { Ageratum } \\
\text { gonyzoides } \\
\text { L }\end{array}$ & $\begin{array}{l}\text { Whole } \\
\text { plant }\end{array}$ & $\begin{array}{l}\text { Pest used for cuts and } \\
\text { wounds. It is also used to } \\
\text { cure for wounds between } \\
\text { two toes caused by muddy } \\
\text { soil in the rainy season. }\end{array}$ \\
\hline
\end{tabular}


Dhaulagiri Journal of Sociology and Anthropology Vol.2 | 243

\begin{tabular}{|c|c|c|c|c|c|}
\hline 34 & Dhairo & \begin{tabular}{|l} 
Fire- \\
flame \\
bush
\end{tabular} & 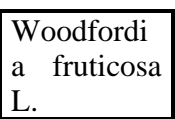 & Flower & $\begin{array}{l}\text { Juice of flower is used in } \\
\text { dysentery and to care of } \\
\text { bleeding in stool. }\end{array}$ \\
\hline 35 & $\begin{array}{l}\text { Dahi } \\
\text { chamle, } \\
\text { Dahi } \\
\text { kamlo. }\end{array}$ & - & \begin{tabular}{|l|} 
Clicarpa \\
macrophyll \\
a L
\end{tabular} & $\begin{array}{l}\text { Roots } \\
\text { and bark }\end{array}$ & $\begin{array}{l}\text { The juice of bark is used in } \\
\text { fever, inflammation and } \\
\text { body ache. }\end{array}$ \\
\hline 36 & Dansinki & $\begin{array}{l}\text { Maiden } \\
\text { hair fern }\end{array}$ & $\begin{array}{l}\text { Adiantum } \\
\text { venustum } \\
\text { D. Don. }\end{array}$ & $\begin{array}{l}\text { Whole } \\
\text { plant }\end{array}$ & $\begin{array}{l}\text { Juice is used to cure of } \\
\text { abdominal disorder, cough } \\
\text { and scorpion stings. }\end{array}$ \\
\hline 37 & Dhursul & - & \begin{tabular}{|l|} 
Colebrooke \\
a \\
oppositifola \\
L.
\end{tabular} & \begin{tabular}{|l|} 
Roots \\
and top \\
most \\
shoots
\end{tabular} & $\begin{array}{l}\text { Root juice is used in } \\
\text { epilepsy and the juice of } \\
\text { shoots is used to cure of } \\
\text { sinuses and wounds. }\end{array}$ \\
\hline 38 & Githa & $\begin{array}{l}\text { Air } \\
\text { potato }\end{array}$ & $\begin{array}{l}\text { Dioscorea } \\
\text { bulbifera } \\
\text { Linn }\end{array}$ & Bulb & $\begin{array}{l}\text { Small pieces are boiled and } \\
\text { applied to kill of stomachic } \\
\text { worms. For this purpose } \\
\text { the people eat it in each } \\
\text { year (May-June). }\end{array}$ \\
\hline 39 & $\begin{array}{l}\text { Ganja, } \\
\text { Bhang, } \\
\text { Bhango }\end{array}$ & Hemp & $\begin{array}{l}\text { Cannabits } \\
\text { sativa L }\end{array}$ & $\begin{array}{l}\text { Leaf, } \\
\text { resinous } \\
\text { exudates. }\end{array}$ & $\begin{array}{l}\text { It is used for stomachic } \\
\text { disorders. } \\
\text { exudates are used inous } \\
\text { diarrhea, dysentery, cholera } \\
\text { and cold. }\end{array}$ \\
\hline 40 & Golkakri & \begin{tabular}{|l|} 
Ivy guard \\
kavai \\
fruit
\end{tabular} & $\begin{array}{l}\text { Coccinea } \\
\text { grandis L. }\end{array}$ & $\begin{array}{l}\text { Roots, } \\
\text { fruit }\end{array}$ & $\begin{array}{l}\text { Fruit is eaten and roots } \\
\text { juice is used for fever, } \\
\text { pneumonia. }\end{array}$ \\
\hline 41 & $\begin{array}{l}\text { Ghiu } \\
\text { kumari }\end{array}$ & $\begin{array}{l}\text { Indian } \\
\text { aloe }\end{array}$ & $\begin{array}{l}\text { Aloea vera } \\
\text { L. }\end{array}$ & Leaf fluid & $\begin{array}{l}\text { Leaf fluid of the plant is } \\
\text { used in burning wounds, } \\
\text { internal inflammation. }\end{array}$ \\
\hline 42 & $\begin{array}{l}\text { Gurjo } \\
\text { laharo }\end{array}$ & |- & \begin{tabular}{|l|} 
Tinospora \\
cordifolia \\
(willed.) \\
Miers \\
\end{tabular} & Stem & $\begin{array}{l}\text { Stem powder and juice in } \\
\text { used in diabetes, body ache } \\
\text { and for local tea. }\end{array}$ \\
\hline 43 & \begin{tabular}{|l} 
Ghod \\
tapre, \\
Topre \\
jhar, \\
Brahmi \\
\end{tabular} & $\begin{array}{l}\text { Water } \\
\text { pemywor } \\
\mathrm{t}\end{array}$ & $\begin{array}{l}\text { Centella } \\
\text { asiatica L }\end{array}$ & $\begin{array}{l}\text { Whole } \\
\text { plant }\end{array}$ & $\begin{array}{l}\text { Juice of plants is used to } \\
\text { cure for fever, jaundice and } \\
\text { internal heat of the body. }\end{array}$ \\
\hline 44 & Gindari & $\begin{array}{l}\text { Headache } \\
\text { tree }\end{array}$ & $\begin{array}{l}\text { Premna } \\
\text { integrifolia } \\
\text { L }\end{array}$ & Bark & $\begin{array}{l}\text { Bark juice is mixed with } \\
\text { the juice of Simal and } \\
\text { Gobhan and used to control } \\
\text { internal heat of body and } \\
\text { increase appetite. }\end{array}$ \\
\hline 45 & Golaicho & - & \begin{tabular}{|l|} 
Clerodendu \\
rm \\
serratum \\
(L.) Moon \\
\end{tabular} & Bark & $\begin{array}{l}\text { Juice of bark is given for } \\
\text { constipation, dysentery and } \\
\text { gastric. }\end{array}$ \\
\hline 46 & Gujar & Fulse & Cissampelo & Bulb & Bulb juice is used in \\
\hline
\end{tabular}

244 | Prakash Prasad Sapkota

\begin{tabular}{|c|c|c|c|c|c|}
\hline & Gano & pareira & s pareira $\mathrm{L}$ & & stomachic disorders. \\
\hline 47 & $\begin{array}{l}\text { Halhale, } \\
\text { Halhale } \\
\text { Sag }\end{array}$ & $\begin{array}{l}\text { Curly } \\
\text { doek }\end{array}$ & $\begin{array}{l}\text { Rumex } \\
\text { crispus L }\end{array}$ & $\begin{array}{l}\text { Root and } \\
\text { leaf. }\end{array}$ & $\begin{array}{l}\text { Leaf decoction is used in } \\
\text { cough, constipation, mouth } \\
\text { disorders. And, root paste } \\
\text { is used to remove the } \\
\text { complication of cuttings, } \\
\text { wounds etc in the skins. }\end{array}$ \\
\hline 48 & Harro & Chebulie & \begin{tabular}{|l|} 
Terminalia \\
chebula \\
Retz \\
\end{tabular} & Fruits & $\begin{array}{l}\text { Powder of fruits is applied } \\
\text { in cough, fever and eye } \\
\text { disease. }\end{array}$ \\
\hline 49 & Khirro & $\begin{array}{l}\text { Tallow } \\
\text { Tree }\end{array}$ & $\begin{array}{l}\text { Sapium } \\
\text { insigne }\end{array}$ & $\begin{array}{l}\text { Leaves \& } \\
\text { Latex }\end{array}$ & $\begin{array}{l}\text { It is used for skin diseases } \\
\text { and insecticide (bio- } \\
\text { pesticide) }\end{array}$ \\
\hline 50 & $\begin{array}{l}\text { Kali } \\
\text { neuro, } \\
\text { Neguro }\end{array}$ & Fern & $\begin{array}{l}\text { Dryoathyri } \\
\text { um } \\
\text { boryanum } \\
\text { (Willd.) } \\
\text { Ching. }\end{array}$ & $\begin{array}{l}\text { Tendril } \\
\text { shoots }\end{array}$ & $\begin{array}{l}\text { It is used for headache, } \\
\text { fever and stomachic } \\
\text { disorders. }\end{array}$ \\
\hline 51 & Kankro & acumbe & $\begin{array}{l}\text { Cucumis } \\
\text { sativus L. }\end{array}$ & $\begin{array}{l}\text { Fruit and } \\
\text { seed }\end{array}$ & $\begin{array}{l}\text { Juice used for internal heat, } \\
\text { and chronic asthma. }\end{array}$ \\
\hline 52 & kurilo & $\begin{array}{l}\text { Asparagu } \\
\mathrm{s}\end{array}$ & $\begin{array}{l}\text { Asparagus } \\
\text { racemosus } \\
\text { L. } \\
\end{array}$ & Tuber & $\begin{array}{l}\text { Decoction of tuber is used } \\
\text { to increase milk in women, } \\
\text { tonic and fever. }\end{array}$ \\
\hline 53 & $\begin{array}{l}\text { Kukurdai } \\
\text { no }\end{array}$ & $\begin{array}{l}\text { Green } \\
\text { briers }\end{array}$ & $\begin{array}{l}\text { Smilex zey } \\
\text { lanica L. }\end{array}$ & Roots & $\begin{array}{l}\text { Root juice is used for } \\
\text { venereal } \\
\text { rheumatism and bloodless } \\
\text { dysentery. }\end{array}$ \\
\hline 54 & khaphal & Mulberry & Morus alba & $\begin{array}{l}\text { Fruit, } \\
\text { Bark }\end{array}$ & $\begin{array}{l}\text { Fruits are eaten to kill thirst } \\
\text { and bark decoction is used } \\
\text { in fever. }\end{array}$ \\
\hline 55 & Kera & Banana & $\begin{array}{l}\text { Musa } \\
\text { paradisiaca } \\
\text { L. } \\
\end{array}$ & $\begin{array}{l}\text { Sap of } \\
\text { rizome }\end{array}$ & $\begin{array}{l}\text { Sap of rhizome is mixed } \\
\text { with sugar and used in } \\
\text { internal inflammation. }\end{array}$ \\
\hline 56 & $\begin{array}{l}\text { Kanthaka } \\
\text { ri }\end{array}$ & $\begin{array}{l}\text { Indian } \\
\text { Salmon }\end{array}$ & \begin{tabular}{|l|} 
Solanum \\
anguivi \\
Lam. (L.) \\
\end{tabular} & Fruit & $\begin{array}{l}\text { Fruit juice is used to reduce } \\
\text { teeth pain piles and in } \\
\text { scabies. }\end{array}$ \\
\hline 57 & $\begin{array}{l}\text { Kurkure, } \\
\text { kurkure } \\
\text { jhar }\end{array}$ & $\begin{array}{l}\text { Toad } \\
\text { stool }\end{array}$ & $\begin{array}{l}\text { Lippia } \\
\text { nodiflora L }\end{array}$ & $\begin{array}{l}\text { Whole } \\
\text { plant }\end{array}$ & $\begin{array}{l}\text { Juice of plant mixed with } \\
\text { the same types of juice of } \\
\text { ghod tapre and akash beli } \\
\text { is used to cure for fever } \\
\text { and jaundice. }\end{array}$ \\
\hline 58 & Kachur & $\begin{array}{l}\text { Wild } \\
\text { turmeric }\end{array}$ & $\begin{array}{l}\text { Cuscuma } \\
\text { zedoarea L. }\end{array}$ & Rhizome & $\begin{array}{l}\text { Juice or powder of rhizome } \\
\text { is used in stomachic } \\
\text { disorders and gastric. }\end{array}$ \\
\hline 59 & Kus & $\begin{array}{l}\text { Sacrificia } \\
\text { l grass }\end{array}$ & $\begin{array}{l}\text { Demostach } \\
\text { ya } \\
\text { bipinnata } \\
\text { (L.) Stapf. } \\
\end{array}$ & $\begin{array}{l}\text { Whole } \\
\text { plants }\end{array}$ & $\begin{array}{l}\text { Juice or decoction in given } \\
\text { to cure of asthma, } \\
\text { jaundices and biliousness. }\end{array}$ \\
\hline 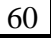 & Kapro, & - & Ficus lacor & Bark & Decoction of bark used for \\
\hline
\end{tabular}


Dhaulagiri Journal of Sociology and Anthropology Vol.2 | 245

\begin{tabular}{|c|c|c|c|c|c|}
\hline & Kabhro & & \begin{tabular}{|l} 
Buch.- \\
Ham.
\end{tabular} & & $\begin{array}{l}\text { ulcer and infection in } \\
\text { leucorrhoea. }\end{array}$ \\
\hline 61 & Lunde & $\begin{array}{l}\text { Spiny } \\
\text { Amaranth } \\
\text { us }\end{array}$ & $\begin{array}{l}\text { Amaranthu } \\
\text { s viridis } L\end{array}$ & Root & $\begin{array}{l}\text { Juice of root is used to cure } \\
\text { of pneumonia of children. } \\
\text { It is also used for colic pain } \\
\text { and leucorrhoea. }\end{array}$ \\
\hline 62 & Lasun & Garlic & $\begin{array}{l}\text { Allium } \\
\text { sativa L }\end{array}$ & $\begin{array}{l}\text { Roots \& } \\
\text { leaves }\end{array}$ & $\begin{array}{l}\text { Juice of root and leaf is } \\
\text { applied for tonic, digestion, } \\
\text { toothache, earaches and } \\
\text { headache. }\end{array}$ \\
\hline 63 & Lauka & $\begin{array}{l}\text { White } \\
\text { flower } \\
\text { gourd }\end{array}$ & $\begin{array}{l}\text { Lagenaria } \\
\text { siceraria L. }\end{array}$ & Seed & $\begin{array}{l}\text { Seed juice is use for the } \\
\text { cure of chronic cough. }\end{array}$ \\
\hline 64 & Okhar & Walnut & $\begin{array}{l}\text { Jujglans } \\
\text { regia L. }\end{array}$ & $\begin{array}{l}\text { Bark of } \\
\text { stem and } \\
\text { fruit. }\end{array}$ & $\begin{array}{l}\text { Paste of bark and fruit is } \\
\text { used to control white spots } \\
\text { in the skin (white leprosy) } \\
\text { and it is also used in other } \\
\text { skin diseases. }\end{array}$ \\
\hline 65 & Pipal & Pipal tree & \begin{tabular}{|l|} 
Ficus \\
religiosa L. \\
\end{tabular} & Bark & $\begin{array}{l}\text { Juice or powder of bark is } \\
\text { used for cough and asthma. }\end{array}$ \\
\hline 66 & Pudina & $\begin{array}{l}\text { Pepper } \\
\text { mint }\end{array}$ & $\begin{array}{l}\text { Mentha } \\
\text { arvensis L. }\end{array}$ & Leaves & $\begin{array}{l}\text { Juice of leaves is used to } \\
\text { cure of digestion, asthma, } \\
\text { and to regulate urine. }\end{array}$ \\
\hline 67 & $\begin{array}{l}\text { Pashanav } \\
\text { ed }\end{array}$ & - & \begin{tabular}{|l|} 
Bergenia \\
ciliate \\
Forma. \\
\end{tabular} & Rhizome & $\begin{array}{l}\text { Decoction of rhizome, used } \\
\text { for fever and diarrhea. It is } \\
\text { used as family planning. }\end{array}$ \\
\hline 68 & Paiyun & $\begin{array}{l}\text { Himalaya } \\
\mathrm{n} \text { wild } \\
\text { cherry }\end{array}$ & \begin{tabular}{|l|} 
Prunus \\
cerasoides \\
D. Don. \\
\end{tabular} & Bark & $\begin{array}{l}\text { Decoction of bark is used } \\
\text { to remove body ache and to } \\
\text { stop abortion. }\end{array}$ \\
\hline 69 & $\begin{array}{l}\text { Raj } \\
\text { briksha }\end{array}$ & $\begin{array}{l}\text { Cassia } \\
\text { pods }\end{array}$ & $\begin{array}{l}\text { Cassia } \\
\text { fistula L }\end{array}$ & Seeds & $\begin{array}{l}\text { Juice of seeds is given to } \\
\text { regulate the stopped } \\
\text { urine,snake bite and } \\
\text { rheumatism. }\end{array}$ \\
\hline 70 & Rudilo & $\begin{array}{l}\text { Night } \\
\text { Jasmin }\end{array}$ & \begin{tabular}{|l|} 
Nyctanthes \\
abor-tristis \\
L. \\
\end{tabular} & Leaf & $\begin{array}{l}\text { Leaf decoction is used to } \\
\text { treat completely for fever } \\
\text { and chronic typhoid. }\end{array}$ \\
\hline 71 & $\begin{array}{l}\text { Sikari } \\
\text { Lahara }\end{array}$ & - & 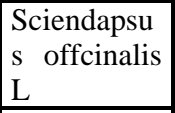 & $\begin{array}{l}\text { Leaves } \\
\text { and stem }\end{array}$ & $\begin{array}{l}\text { Juice is used in cuts. It } \\
\text { controls the cuts } \\
\text { immediately. }\end{array}$ \\
\hline 72 & Simal & $\begin{array}{l}\text { Silk } \\
\text { cotton } \\
\text { Tree }\end{array}$ & $\begin{array}{l}\text { Bombax } \\
\text { ceiba L }\end{array}$ & Bark & $\begin{array}{l}\text { Bark juice mixing with the } \\
\text { bark of Ginderi and Gogan } \\
\text { juice and sugar left during } \\
\text { a whole night outside the } \\
\text { house and used to remove } \\
\text { the internal inflammation } \\
\text { in the body. }\end{array}$ \\
\hline 73 & Siundi & - & \begin{tabular}{|l|} 
Euphorbia \\
royleana \\
Boiss \\
\end{tabular} & Latex & $\begin{array}{l}\text { Latex is used for stomachic } \\
\text { disorders and it is } \\
\text { massaged around navel }\end{array}$ \\
\hline
\end{tabular}

246 | Prakash Prasad Sapkota

\begin{tabular}{|c|c|c|c|c|c|}
\hline & & & & & $\begin{array}{l}\text { when the stomach starts to } \\
\text { pain. }\end{array}$ \\
\hline 74 & Sajimal & $\begin{array}{l}\text { Physic } \\
\text { nut }\end{array}$ & $\begin{array}{l}\text { Jatropha } \\
\text { curcas L }\end{array}$ & $\begin{array}{l}\text { Latex } \\
\text { (sap) }\end{array}$ & $\begin{array}{l}\text { Latex used for cuts and } \\
\text { wounds especially in the } \\
\text { wounds between two toes } \\
\text { in the rainy season. }\end{array}$ \\
\hline 75 & Satuwa & - & $\begin{array}{l}\text { Paris } \\
\text { polyhylla } \\
\text { L. }\end{array}$ & Rhizome & $\begin{array}{l}\text { Decoction of rhizome is } \\
\text { used to control the poison } \\
\text { and applied in cuts. }\end{array}$ \\
\hline 76 & Sisnu & $\begin{array}{l}\text { Stinging } \\
\text { nettle }\end{array}$ & $\begin{array}{l}\text { Urtica } \\
\text { dioica L }\end{array}$ & $\begin{array}{l}\text { Root and } \\
\text { shoots }\end{array}$ & $\begin{array}{l}\text { Juice or decoction of root } \\
\text { and shoot is used to cure } \\
\text { for anemia, to purify blood } \\
\text { and for tonic. }\end{array}$ \\
\hline 77 & Siltmur & - & $\begin{array}{l}\text { Litsea } \\
\text { cubeba L. } \\
\text { or Lindera } \\
\text { neesiana }\end{array}$ & Fruit & $\begin{array}{l}\text { Fruits directly or its } \\
\text { decoction is used to cure of } \\
\text { fever, cough and to control } \\
\text { poison. }\end{array}$ \\
\hline 78 & Simali & $\begin{array}{l}\text { Indian } \\
\text { privet }\end{array}$ & $\begin{array}{l}\text { Vitex } \\
\text { negundo L. }\end{array}$ & Shoots & $\begin{array}{l}\text { One to two drops of Juice } \\
\text { of shoots are used to cure } \\
\text { of sinuses. }\end{array}$ \\
\hline 79 & Sipligan & - & $\begin{array}{l}\text { Crataeva re } \\
\text { ligiosa } \\
\text { Hook \& } \\
\text { at. al. }\end{array}$ & $\begin{array}{l}\text { Fruit, } \\
\text { shoots, } \\
\text { bark }\end{array}$ & $\begin{array}{l}\text { Juice of fruit, shoot and } \\
\text { bark is applied to cure of } \\
\text { snake bite, infected wounds } \\
\text { and cuts. It increase } \\
\text { appetite and controls other } \\
\text { skin diseases. }\end{array}$ \\
\hline 80 & Titepati & Mugwort & $\begin{array}{l}\text { Artemisia } \\
\text { dubia L }\end{array}$ & $\begin{array}{l}\text { Whole } \\
\text { plants }\end{array}$ & $\begin{array}{l}\text { It is used for stomachic, } \\
\text { purgative, hysteria asthma, } \\
\text { skin disease like scabies \& } \\
\text { on ulcers. }\end{array}$ \\
\hline 81 & $\begin{array}{l}\text { Tite } \\
\text { karela }\end{array}$ & $\begin{array}{l}\text { Bitter } \\
\text { cucumber }\end{array}$ & $\begin{array}{l}\text { Momordica } \\
\text { charantia L. }\end{array}$ & Fruit & $\begin{array}{l}\text { Decoction is used to cure } \\
\text { for fever, to Purify blood } \\
\text { and increase in appetite. }\end{array}$ \\
\hline 82 & Tulasi & $\begin{array}{l}\text { Scred } \\
\text { basil }\end{array}$ & $\begin{array}{l}\text { Ocimum } \\
\text { tenmifloru } \\
\text { m L }\end{array}$ & $\begin{array}{l}\text { Leaf, } \\
\text { Whole } \\
\text { plants }\end{array}$ & $\begin{array}{l}\text { Juice of plant is used in } \\
\text { fever earache and infection, } \\
\text { cough, sores of moth and } \\
\text { fever. }\end{array}$ \\
\hline 83 & $\begin{array}{l}\text { Tejpat, } \\
\text { Sinkauli }\end{array}$ & $\begin{array}{l}\text { Indian } \\
\text { cassia }\end{array}$ & $\begin{array}{l}\text { Cinnanomu } \\
\text { m tamala L }\end{array}$ & $\begin{array}{l}\text { Leaf \& } \\
\text { bark }\end{array}$ & $\begin{array}{l}\text { Decoction of leaf and bark } \\
\text { is used in headache, fever } \\
\text { and constipation. }\end{array}$ \\
\hline 84 & $\begin{array}{l}\text { Timur, } \\
\text { Raya } \\
\text { timur }\end{array}$ & $\begin{array}{l}\text { Nepali } \\
\text { peeper }\end{array}$ & $\begin{array}{l}\text { Zanthoxylu } \\
\text { m armatum } \\
\text { Dc. }\end{array}$ & Fruit & $\begin{array}{l}\text { Decoction of fruits is used } \\
\text { in fever, cough, asthma, } \\
\text { headache, teeth ache and } \\
\text { digestion. }\end{array}$ \\
\hline 85 & $\begin{array}{l}\text { Timilo, } \\
\text { Goppha }\end{array}$ & - & $\begin{array}{l}\text { Ficus } \\
\text { sarmentosa } \\
\text { Buch.- } \\
\text { Ham. ex } \\
\text { Sm. }\end{array}$ & Fruit (fig) & $\begin{array}{l}\text { At the time of stomachic } \\
\text { pain and diarrhea, the fruits } \\
\text { are directly applied in fresh } \\
\text { form. }\end{array}$ \\
\hline 86 & Thakailo & - & $\begin{array}{l}\text { Morina } \\
\text { polyphylla } \\
\text { Wall. Ex. } \\
\text { Dc. }\end{array}$ & $\begin{array}{l}\text { Root and } \\
\text { shoot }\end{array}$ & $\begin{array}{l}\text { Juice of root and shoot is } \\
\text { used to cure of swelling, } \\
\text { Gastritis, painful joints and } \\
\text { internal inflammation of } \\
\text { body. }\end{array}$ \\
\hline
\end{tabular}




\section{8 | Prakash Prasad Sapkota}

Source: Field Survey 2008

The medicinal plants are useful to treat fever, cough, cold, headache, removing worms, asthma, jaundice, gynecological disease of female, cut, wounds, gastric and heating sensation. They are mostly used in the form of juice, powder, decoction, paste, liquid form, goli etc.

They use 17 plant species for fodder, 10 species of cultivated crop plant species and 6 varieties of rice. They have 14 species used for making agricultural equipments and 25 wild edible plants.

They use 23 kinds of different plant species in rituals and ceremonies; they are given in the table 2.

Table 2: Plant species used in rituals and ceremonies

\begin{tabular}{|c|l|l|}
\hline S.N. & Nepali Local name & \multicolumn{1}{|c|}{ Botanical name } \\
\hline 1. & Amp. & Magnifier indicia. \\
\hline 2. & Babiyo & Eulalioplis binate \\
\hline 3. & Bans & Dendrocalamus spp. \\
\hline 4. & Bet lauri & Costus sperlosus \\
\hline 5. & Dubo & - \\
\hline 6. & Jhakro & Musa paradicica \\
\hline 7. & kera & Quercus semicarpifolia \\
\hline 8. & kharsu & Asparagus racemosus \\
\hline 9. & kurilo & Smilex zeylanica L. \\
\hline 10. & kukurdaino & Poinsettia pulcherima \\
\hline 11. & lalupati & - \\
\hline 12. & lute jhar & - \\
\hline 13. & Magarkanchi & Ficus religiosa L. \\
\hline 14. & pipal & Purunus cerasoides \\
\hline 15. & painyu & Oriza sativa \\
\hline 16. & rice & Pteridophyta sp. \\
\hline 17. & saldhoti & Imperate cylindrical L. \\
\hline 18. & siru & - \\
\hline 19. & shrikhanda & Artemisia valgaris \\
\hline 20. & titepati & Dioscorea bulbifera \\
\hline 21. & Tarul & Triticusm aestivum \\
\hline 22. & wheat (gahu) & Ocimum tenmiflorum L. \\
\hline 23 & Tulsi & \\
\hline & &
\end{tabular}

Source: field survey 2008 (Sapkota, 2007)

- Amp, Dubo, Kara, Painyu, rice, titepati,pipal, gahu babio.- used in reverence ceremonies and bartabanda.

- Kharsu- used in bartabanda, birth rites

- Betlauri, kurilo, kukur daino, lute jhar, shal dhoti, siru, Magarkachi - used in shawune sankranti \& luto falne

- Baans, jhankro, shreekhanda, lalupate, Tulsi - used in death rites.

- Tarul - used in Maghe Sankranti

\section{Changing Situation}

The Magars of Bukini, struggle with the environment by changing their habit and habitat. The economic condition is changed by improving the number of educated people. Most of the young left to drink wine frequently. They struggle to engage in government as well as foreign jobs. They are improving their agricultural production using hybrid seeds and chemical fertilizer. In this area different clan of Magars are migrated from different places. They have different knowledge, moral, belief and symbolic identity also. They are intermixed each other socially as well as culturally. Any one's culture is unable to dominate the other but co-dominate and not develop a new one, till now. According to their norms they can marry in different clan and seen diff. Character's governed hybrid chield. The purity of Mangolian face is seen clearly in Chiple Magar but Singali, Bagale, Bhujel, Dhemal, Pedalne and chilies have in between Mangolian and Aryan when noticed on nosal \& check bone of the face as well as colour. Young male as well as female have changed their habit of fooding and dressing. They want to eat synthesized food like noodles, cake, sweets in place of maize \& wheat bread. Male wears paint, shirt, T-shirt in place of east-coat, kachad \& cap. Female wears cholo, T-shirt and madbari, 
bulaki and naugadi. Widow marriage is extinct and in marriage ceremony they have started to use sindur though their parents did not. In Dashain and Tihar older people use curd and rice mixture white aaccheta but now a day younger have started to use aabir.

Now, almost all the people use tap water for drinking purpose and use toilet. They are aware about sanitation but do not left pig farming in front of their houses by Chiple Magars. In delivery time, most of the females visit hospital and follow the rule of hospital's vaccination program for their newly born child. Most of the people left Jhamre and use radio, T.V. and film for recreation. They totally left their language and mother tongue is Nepali now. They have started to use Tulsi ko pani [leaf of Ocimum tenmiflorum and water] in the mouth of dead body for purity and started to bang a conch which was not in past. Herbal medicine has no side-effects and cheaper is not in practice now. Most of the people are not familiar with the effect and importance of medicinal plants and left to use. Only elder few people have deep knowledge about it \& practice a little which led dangerous situation to adjust with their environment. Some of them now feel that we should save our culture which helps them to adjust easily with their environment.

\section{Discussion}

The Magars of Bukini are struggling with environment increasing economic condition and education but their saving rate is not higher. The rate of dependency is increasing on fooding, clothing and recreation activity. The economic condition of most of the families is poor \& two families have no land and on the other hand the rate of expenditure is increasing day by day. The numbers of educated people have increased but they do not have applied knowledge about agricultural production \& are not attracted or interested about agricultural work. Then agricultural land changes into barren land. Than how sustainable, economic development occurs? The knowledge should be use to sustain easily by proper use of local resource but most of the people have not increase such type of knowledge. Only a few people have important knowledge about plant people relation and adjust with their environment. The knowledgeable people are also left to practice useful medicinal plants. If they will die their knowledge will be vanish. The younger educated people should be aware about the importance of the indigenous knowledge and improve it according to the changing situation of people \& their society.

\section{Conclusion}

Socio-cultural and ethno-botany is the multidisciplinary approach including the methods, theories and concepts of sociology, anthropology and botany. Magars of Bukini have left their language, traditional technology but they have their own ethno-history, belief system which are functional in relation to their social system and ecosystem. The major subsistence strategy of the Magar's is agriculture and animal husbandry. But only a few families can sustain from their agricultural product because they have less productive land. The numbers of educated people has increased but they do not have applied knowledge about agricultural production and are not attracted or interested about agricultural work. The agricultural land is changing into barren land. Their economic condition is not so poor in economic aspect except agricultural work, females are struggling for independence by preparing and selling liquor in free time and males are engaged in national and international jobs. The education and health condition is good. Only $23.33 \%$ are illiterate which is less than national figure. The elder Magars are rich in sustainable indigenous knowledge and legends but younger are not. The cultural identity show emotional ties towards plant people relationship. Only few people have knowledge about medicinal plants though, they left the practice of useful 


\section{Dhaulagiri Journal of Sociology and Anthropology Vol.2 | 251}

medicinal plants. The investigation shows an intimate interrelationship between people, culture and their natural environment, which influence the social status of the people.

Massive exploitations of useful plants, lack of awareness is leading extinction and destruction of biodiversity. This paper is prepared to high light this janajati, document, revive and transmit the socio-cultural, ethno-botanical and changing situation of Magar's development and for the maintenance of socio-cultural identity.

(Note: Hearty thanks to all the respondents who helped in field study, mainly Lal Bahadur Thapa, Tika Ram Thapa, Chabilal Thapa, Kali Thapa Durga Thapa and Ganesh Thapa.)

\section{Reference}

Bhattarai, N.K. (1992). Medicinal Ethnology in the Karnali Zone. Economic Botany 46(3).

Coburn, B. 1484, Some Native Medicinal Plants of the Western, Gurung Kailash: A Journal of Himalayan Studies 11

Durivedi, P.K. (1982). Nepalese Society. Kathmandu: National Museum, Nepal.

Gurung D.J. (1994). Indigenous Knowledge and Biodiversity. Kathmandu: ICMOD, Nepal.

HMG/N (1970). Medicinal Plants of Nepal. Bull. No. 3. Development of Medicinal Plants.

Malla, S.B and Shakya P.R. (1984). Vegetation and Medicinal Plants of Nepal. Development of Medicinal Plants, Ktm.

Manandhar, N.P. (1996). A Contribution of the Ethno-botany of Mooshar Tribes of Dhanusa District Ktm:J. Matlist Press, Nepal.

Sapkota, Sarkar, Shakya and Shrestha (1994). Indigenous Medicinal and Non-commercial Food Plants in Village of Palpa

\section{$252 \mid$ Prakash Prasad Sapkota}

and Parsa District WWF, Nepal

Sapkota, P.P (2000). Ecological Study and Traditional Uses of Medicinal Plants at Malika forest Baglung, A Dissertation Submitted to the Department of Botany T.U. Ktm.

Sapkota, P.P. (2005). Socio-Cultural and Ethno-botanical Knowledge of Aidy: An Anthropological study of Mimi VDC of Humla. Dhaulagiri Journal of Sociology and Anthropology, M.M.C. Baglung.

Sapkota, P.P. (2007), Ethno-botany: An Anthropological Observation of Magar of Baglung Municipality-9 Langaun. Pragya-Sarathi M.M.C. Baglung

Sharma, P.R. (1995). Culture and Tourism: Defining Roles and Relationship. Kathmandu: ICIMOD, Nepal.

Shrestha P. (1985). Research Note contribution to the Ethnobotany of the Palpa area. Vol. 12 No.2, Kathmandu: CNAS.

Steward, J. (1955). Theory of Cultural Change, Urban: University of Illinois press.

True, (1990). Epidemiology and Medical Anthropology, in Thomas M. Johnson and Sergeant Carolyn: USA Paper Publisher. 